University of Nebraska - Lincoln

DigitalCommons@University of Nebraska - Lincoln

Biological Systems Engineering: Papers and

Publications

Biological Systems Engineering

$11-4-2016$

\title{
Effect of rainfall timing and tillage on the transport of steroidhormones in runoff from manure amended row crop fields
}

Sagor Biswas

Dept. of Population Health and Reproduction, Univ. of California, sabiswas@ucdavis.edu

William L. Kranz

Dept. of Biological Systems Engineering, Univ. of Nebraska-Lincoln, Haskell Agricultural Laboratory, wkranz1@unl.edu

Charles A. Shapiro

Dept. of Agronomy and Horticulture, Univ. of Nebraska-Lincoln, Haskell Agricultural Laboratory, cshapiro1@unl.edu

Daniel D. Snow

Nebraska Water Center and School of Natural Resources, Univ. of Nebraska-Lincoln, dsnow1@unl.edu

Shannon L. Bartelt-Hunt

Dept. of Civil Engineering, Univ. of Nebraska-Lincoln, Peter Kiewit Institute, sbartelt2@unl.edu

Follow this and additional works at: https://digitalcommons.unl.edu/biosysengfacpub Soe next page for additional authors

Part of the Bioresource and Agricultural Engineering Commons, Environmental Engineering Commons, and the Other Civil and Environmental Engineering Commons

Biswas, Sagor; Kranz, William L.; Shapiro, Charles A.; Snow, Daniel D.; Bartelt-Hunt, Shannon L.; Mamo, Mitiku; Tarkalson, David D.; Zhang, Tian C.; Shelton, David P.; van Donk, Simon J.; and Mader, Terry L., "Effect of rainfall timing and tillage on the transport of steroidhormones in runoff from manure amended row crop fields" (2016). Biological Systems Engineering: Papers and Publications. 565.

https://digitalcommons.unl.edu/biosysengfacpub/565

This Article is brought to you for free and open access by the Biological Systems Engineering at DigitalCommons@University of Nebraska - Lincoln. It has been accepted for inclusion in Biological Systems Engineering: Papers and Publications by an authorized administrator of DigitalCommons@University of Nebraska Lincoln. 


\section{Authors}

Sagor Biswas, William L. Kranz, Charles A. Shapiro, Daniel D. Snow, Shannon L. Bartelt-Hunt, Mitiku Mamo, David D. Tarkalson, Tian C. Zhang, David P. Shelton, Simon J. van Donk, and Terry L. Mader 


\title{
Effect of rainfall timing and tillage on the transport of steroid hormones in runoff from manure amended row crop fields
}

\author{
Sagor Biswas ${ }^{a}, *$, William L. Kranz ${ }^{b}$, Charles A. Shapiro ${ }^{c}$, Daniel D. Snow ${ }^{\mathrm{d}}$, \\ Shannon L. Bartelt-Hunt ${ }^{\mathrm{e}}$, Mitiku Mamo ${ }^{\mathrm{b}}$, David D. Tarkalson ${ }^{\mathrm{f}}$, Tian C. Zhang ${ }^{\mathrm{e}}$, \\ David P. Shelton ${ }^{\mathrm{b}}$, Simon J. van Donk ${ }^{\mathrm{g}}$, Terry L. Mader ${ }^{\mathrm{h}}$
}

a Dept. of Population Health and Reproduction, Univ. of California, Davis, CA 95616, United States

${ }^{\mathrm{b}}$ Dept. of Biological Systems Engineering, Univ. of Nebraska-Lincoln, Haskell Agricultural Laboratory, 57905 866 Road, Concord, NE 68728-2828, United States

${ }^{c}$ Dept. of Agronomy and Horticulture, Univ. of Nebraska-Lincoln, Haskell Agricultural Laboratory, 57905866 Road, Concord, NE 68728-2828, United States

${ }^{\mathrm{d}}$ Nebraska Water Center and School of Natural Resources, Univ. of Nebraska-Lincoln, 202 Water Sciences Laboratory, Lincoln, NE 68583-0844, United States

e Dept. of Civil Engineering, Univ. of Nebraska-Lincoln, Peter Kiewit Institute, Omaha, NE 68182-0178, United States

${ }^{f}$ USDA-ARS, NW Irrigation and Soils Research Lab, 3793 N. 3600 E., Kimberly, ID 83341-5076, United States

${ }^{g}$ Iteris, Inc., 4324 University Ave, Grand Forks, ND 58203, United States

h Dept. of Animal Science, Univ. of Nebraska-Lincoln, Haskell Agricultural Laboratory, 57905866 Road, Concord, NE 68728-2828, United States

\section{H I G H L I G H T S}

- Hormones and metabolites were detected in runoff from test plots fertilized with cattle manure.

- Composting can reduce the hormone concentration in manure compared to stockpiling.

- About $10 \%$ of applied hormones can be lost through the dissolved phase of runoff.

\section{A R T I C L E I N F O}

\section{Article history:}

Received 12 May 2016

Received in revised form 19 October 2016

Accepted 2 November 2016

Available online 4 November 2016

\section{Keywords:}

Steroid hormone

Rainfall

Runoff

Tillage

Manure management

\begin{abstract}
A B S T R A C T
Runoff generated from livestock manure amended row crop fields is one of the major pathways of hormone transport to the aquatic environment. The study determined the effects of manure handling, tillage methods, and rainfall timing on the occurrence and transport of steroid hormones in runoff from the row crop field. Stockpiled and composted manure from hormone treated and untreated animals were applied to test plots and subjected to two rainfall simulation events 30 days apart. During the two rainfall simulation events, detection of any steroid hormone or metabolites was identified in $8-86 \%$ of runoff samples from any tillage and manure treatment. The most commonly detected hormones were $17 \beta$-estradiol, estrone, estriol, testosterone, and $\alpha$-zearalenol at concentrations ranging up to $100-200 \mathrm{ng} \mathrm{L}^{-1}$. Considering the maximum detected concentrations in runoff, no more than $10 \%$ of the applied hormone can be transported through the dissolved phase of runoff. Results from the study indicate that hormones can persist in soils receiving livestock manure over an extended period of time and the dissolved phase of hormone in runoff is not the preferred pathway of transport from the manure applied fields irrespective of tillage treatments and timing of rainfall.
\end{abstract}

(C) 2016 Elsevier B.V. All rights reserved.

\section{Introduction}

The occurrence of natural and synthetic hormones in surface water is a concern to the scientific community due to potential

\footnotetext{
* Corresponding author.

E-mail address: sabiswas@ucdavis.edu (S. Biswas).
}

impacts from chronic exposure to aquatic organisms and public health at low nanogram per liter concentrations [1-4]. Runoff from the crop fields treated with livestock manure generated in the Concentrated Animal Feeding Operations (CAFOs) can be a potential source of hormones to the surface water. The increased density of animals in CAFOs generates greater amounts of manure often with insufficient land area for distribution at agronomic rates. Like all other animals, cattle excrete endogenous hormones through feces 
and urine as a natural physiological process. In addition to that, almost $96 \%$ of the cattle in U.S. CAFOs receive steroid hormone treatments for growth promotion through implants behind the ear or as feed additives [5]. Based on typical hormone excretion rates, each year an estimated $43 \mathrm{Mg}$ of hormones can be released to the environment from approximately 15 million $\mathrm{Mg}$ of manure generated by feedlot cattle [6-8]. In the U.S., treatment of animal manure is not required as long as it is not discharged directly into surface water. A significant portion of this manure (if not all) is applied to agricultural fields as a source of fertilizer. Therefore, surface runoff from manure amended fields can potentially transport hormones from cropland to surface water resources $[9,10]$.

The environmental fate of hormones and their metabolites is complex. After excretion in feces or urine, hormones and metabolites generally change forms through chemical and microbial transformation $[11,12]$. Both natural and synthetic hormones and their metabolites have been detected in manure, soil and wastewater of cattle feedlots [13-16]. Studies evaluating the persistence of specific hormones in soils observed that most steroid hormones and their metabolites exhibit relatively strong adsorption-desorption characteristics with low aqueous solubility [17-19]. Soil microbiology and surrounding physio-chemical characteristics are major factors controlling transformation among the steroid hormones and their metabolites. For example, Mansell et al. [20] reported the presence of parent hormones such as $17 \alpha$-estradiol, $17 \beta$ estradiol, and testosterone (ranging from 5 to $175 \mathrm{ng} \mathrm{L}^{-1}$ ) in runoff from feedlot surface during a rainfall simulation event conducted immediately after the animals were removed from the pens but they found the presence of metabolites such as estrone, androstenedione, and progesterone (ranging from 50 to $250 \mathrm{ng} \mathrm{L}^{-1}$ ) in runoff when they conducted another rainfall simulation 7 days later. They concluded that the dominant forms of hormones and metabolites were determined by changing soil microbial composition along with surrounding physio-chemical properties of the soil. Thus, the likelihood for occurrence of these common forms of hormones or metabolites in surface water is greater from soil near the vicinity of CAFOs [21-23]. Studies have detected the presence of four types of natural and synthetic hormones, namely androgens ( $17 \alpha$ - and $17 \beta$-trenbolone), estrogens (estrone, $17 \beta$-estradiol and estriol) and progestogens (progesterone and melengestrol acetate) in river water samples and identified their adverse impacts on aquatic life (e.g., fathead minnow) at different sites impacted by livestock production facilities along the Elkhorn River in Nebraska [22,24,25]. Result from a study in Israel found that hormones can be detected in rivers up to $60 \mathrm{~km}$ away from a CAFO [26].

A review of the literature suggests that although the occurrence of natural and synthetic hormones at various sites in manure, soil, and water has been well documented, there are no efforts that determine the transport of all four major steroid hormone categories in runoff from crop fields under different agricultural management practices. Considering this knowledge gap, this study was designed to evaluate the performance of two common manure handling (compost and stockpiling) and three tillage practices (disk, moldboard plow with disk, and no-till) on the occurrence of steroid hormones in surface runoff from two one-month-apart rainfall events. It was hypothesized that manure treatment can reduce the concentration of hormones; the types of soil, timing of rainfall, and tillage can play a significant role to influence the transport of hormone through runoff. To verify the hypothesis, artificial rainfall was applied to row crop fields amended with beef cattle manure to determine the impact of rainfall timing, manure, and tillage practices on the concentration of hormones and their associated metabolites in surface runoff from row crop fields.

\section{Materials and methods}

\subsection{Feedlot and manure management}

This study was conducted at the Haskell Agricultural Laboratory of the University of Nebraska-Lincoln near Concord, Nebraska, U.S. $\left(42^{\circ} 22^{\prime} 52.7^{\prime \prime} \mathrm{N}, 96^{\circ} 57^{\prime} 31.3^{\prime \prime} \mathrm{W}\right)$. Soils at the site were mapped as a Nora silty clay loam (fine-silty, mixed, mesic Udic Haplustolls) with $28 \%$ sand, $48 \%$ silt, and $24 \%$ clay and organic carbon fraction $\left(f_{o c}\right)$ of $2.2 \%$ [27]. The soil has permeability in the range of $15-50 \mathrm{~mm} \mathrm{~h}^{-1}$ and available water holding capacity of $0.17-0.22 \mathrm{~mm} \mathrm{~mm}^{-1}$ soil [28]. The study area has an average annual rainfall of $672 \mathrm{~mm} \mathrm{y}^{-1}$ and average annual temperature of $8^{\circ} \mathrm{C}$ [29].

Ninety-six heifers (average weight $230-270 \mathrm{~kg}$ ) that received no hormone treatments prior to the experiment were split into two groups and housed in six pens (16 animals in each). One group of three pens contained animals that was treated with Ralgro ${ }^{\mathrm{TM}}$ ( $36 \mathrm{mg}$ of $\alpha$-zearalanol) and Revalor ${ }^{\mathrm{TM}}-\mathrm{H}$ (140 mg of trenbolone acetate and $14 \mathrm{mg}$ of $17 \beta$-estradiol benzoate) and fed an additive $\mathrm{MGA}^{\circledR} 200$ Premix $(0.45 \mathrm{mg}$ of melengestrol acetate per animal per day) with daily rations. The remaining group (control/untreated) of three pens contained animals that received no implants and were fed regular rations. In each pen, the accumulated manure was collected after cattle were removed from the pens after the 112 days trials. The detailed description of the cattle feeding study in the feedlot is described in Bartelt-Hunt et al. [14].

Collected manure from each pen was then split into two piles, one for composting and one for stockpiling. Twelve manure piles (six of compost piles and six of stockpiled) were stored on a concrete pad under a roof to prevent rainfall from entering the manure piles. The stockpiled manure was stored under roof and remained undisturbed before application to the test plots. For compost piles, corn silage was added to create a manure: silage ratio of $21: 1$ on a dry weight basis to increase the carbon content. A one-time application of $379 \mathrm{~L}$ of water was applied to each compost pile. The corn silage and water were thoroughly mixed using a skid loader. The compost piles were turned weekly for the first four weeks and then biweekly for the next eight weeks to facilitate proper aeration during the composting process. The temperature of the compost pile went up to $55^{\circ} \mathrm{C}$ during the second to third week of composting and gradually went down after that. The complete description of manure management study is supplied in Bartelt-Hunt et al. [15].

The average weight of each pile was estimated to be between 3600 and $4000 \mathrm{~kg}$. Four manure types were produced: 1) composted manure from hormone treated animals (CT);2) composted manure from untreated animals (CU); 3) stockpiled manure from hormone treated animals (ST); and 4) stockpiled manure from untreated animals (SU). At the end of composting and stockpiling period, manure samples were collected from bottom, top, center, and outer edges of a pile. Samples of a pile were then mixed in a stainless steel bucket (cleaned with methyl alcohol) to make a composite sample of each pile, and frozen before sending to the laboratory for analysis. The chemical and physical properties of the manure are provided in Table 1.

\subsection{Rainfall simulation study}

Research plots were established in a continuous corn field that had been under no-till practices for more than 5 years. Plots were oriented in the up-and-down hill direction with an average field slope of $8 \%$. Manure was applied to a plot at either an application rate of $193 \mathrm{Mg} \mathrm{ha}^{-1}$ (wet weight) of stockpiled manure or $159 \mathrm{Mg} \mathrm{ha}^{-1}$ (wet weight) of composted manure to meet soil nitrogen requirements. The recommended nitrogen requirements are $170 \mathrm{~kg}-\mathrm{N} \mathrm{ha}^{-1}$ for dryland continuous corn in northeast Nebraska 
Table 1

Summary of the properties of stockpiled and composted manure.

\begin{tabular}{|c|c|c|c|c|c|c|c|}
\hline & $\mathrm{pH}$ & Moisture content (\%) & $\mathrm{OM}(\%)$ & $\mathrm{OC}(\%)$ & Total N (\%) & $\mathrm{ON}(\%)$ & $\mathrm{C}: \mathrm{N}$ \\
\hline Stockpile & 7.7 & 15 & 13.1 & 7.6 & 0.66 & 0.58 & 11.4 \\
\hline Compost & 7.8 & 21 & 14.0 & 8.1 & 0.76 & 0.70 & 10.6 \\
\hline
\end{tabular}

$\mathrm{OM}=$ organic matter, $\mathrm{OC}=$ organic carbon; $\mathrm{ON}=$ organic nitrogen; $\mathrm{C}: \mathrm{N}=$ ratio of total percent organic carbon to total percent nitrogen; sample size, $\mathrm{n}=6$.

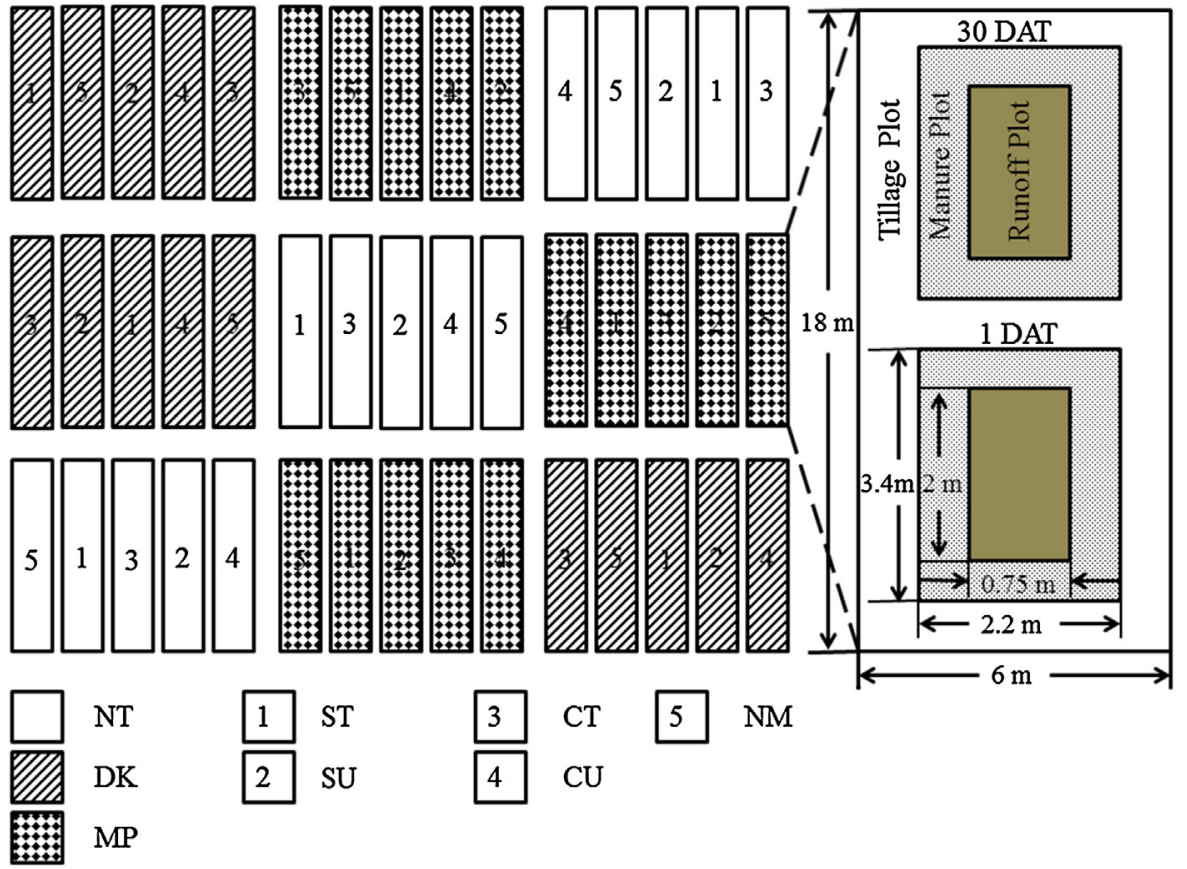

Fig. 1. Schematic of runoff plots along with the experimental design.

[30]. Tillage treatments occurred immediately after manure application.

The statistical design was a randomized complete block design in a split-plot arrangement with three replications [31]. Three tillage treatments: 1) no-till (NT); 2) single disk (DK); and 3) moldboard plow plus single disk (MP), were randomly assigned to the whole plots where the five manure treatments (CT, CU, ST, SU, and control- NM) were applied randomly to the subplots (Fig. 1). Each tillage block was approximately $30 \mathrm{~m}$ wide and $18 \mathrm{~m}$ long and received a single pass over the plot. Each of the 5 manure subplots was $5 \mathrm{~m}$ wide by $18 \mathrm{~m}$ long. Each manure subplot was further divided into 2 sub-subplots that were $2.2 \mathrm{~m}$ wide and $3.4 \mathrm{~m}$ long to allow two rainfall simulation events: one day after manure treatment ( 1 DAT) and 30 days after manure treatment (30 DAT). In the center of the $2.2 \mathrm{~m} \times 3.4 \mathrm{~m}$ plot area, a runoff plot $0.75 \mathrm{~m}$ wide by $2.0 \mathrm{~m}$ long was isolated on three sides by galvanized steel borders. A $150-\mathrm{mm}$ I.D. PVC pipe with a $2.6 \mathrm{~m}$ long by $100 \mathrm{~mm}$ wide slot, cut lengthwise, was used to collect runoff and deliver the runoff to the collection site outside the water application area (Fig. 2). To prevent bypass flow around the collection pipe, a piece of "L" shaped galvanized steel was pressed into the soil at the downstream end of the plot and directed runoff water into the PVC pipe. All borders and drain pipes were pressure washed prior to use on another plot.

Several natural rainfall events totaling $107 \mathrm{~mm}$ were recorded 30 days prior to conducting the 1DAT rainfall simulation. During the 30 days between the two rainfall simulation experiments, the plots were undisturbed and a total of $43 \mathrm{~mm}$ of natural rainfall was recorded by the HPRCC weather station located less than $0.5 \mathrm{~km}$ from the field site (Fig. 3). Simulated rainfall was applied at a rate of approximately $70 \mathrm{~mm} \mathrm{~h}^{-1}$ using a rainfall simulator as described by Humphry et al. [32]. Each rainfall simulator had only one nozzle located at the center of the frame, and positioned $3 \mathrm{~m}$ above the surface of the plot. Water ( $\mathrm{pH} 7.4$ ) was used from the main irrigation well at the Haskell Agricultural Lab. The pressure at the nozzle was maintained at 15 psi to generate the required rainfall intensity. The water application rate was equivalent to the rainfall intensity index (EI) of a single rain storm event expected to occur once every two years in the study area [33].

Rainfall was applied to each plot until runoff occurred for $30 \mathrm{~min}$. The amount of rainfall for each plot was recorded using a water meter attached to the rainfall simulator. Rainfall starting times and runoff initiation times were recorded for each plot. Runoff samples ( $270 \mathrm{~mL}$ amber jars) were collected from each plot at 5, 10, 15, 20,25 , and $30 \mathrm{~min}$ after initiation of runoff. Runoff volumes were calculated using the runoff flow rates recorded at each sampling interval. In total, 270 runoff samples were collected during each rainfall simulation experiment and frozen at $-20^{\circ} \mathrm{C}$ until analyzed for 17 hormones or metabolites at the Water Sciences Laboratory of the University of Nebraska-Lincoln. The experiment was repeated again 30 days after manure application (30 DAT).

\subsection{Steroid hormone analysis}

Runoff water samples were analyzed using on-line solid phase extraction (SPE) liquid chromatography-tandem mass spectrometry (LC/MS/MS) with a Spark Holland Symbiosys Environ automated extraction system (Spark Holland, AJ Emmen, The Netherlands) and a Waters Quattro Micro liquid chromatograph tandem mass spectrometer (Waters Corporation, Milford, MA, USA) system with atmospheric pressure photoionization (APPI) source. Microwaveassisted solvent extraction (MASE) was used for manure samples. The instrument detection limits, method detection limit and aver- 
Table 2

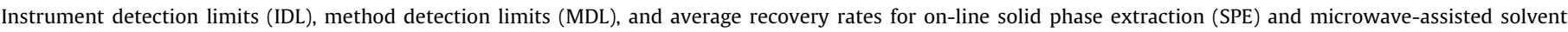

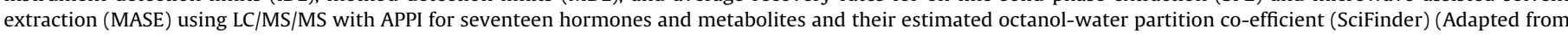
Snow et al. [34]).

\begin{tabular}{|c|c|c|c|c|c|c|c|}
\hline & Hormones and Metabolites & IDL (pg) & $\begin{array}{l}\text { Online SPE MDL } \\
\left(\mathrm{ng} \mathrm{L}^{-1}\right)\end{array}$ & $\begin{array}{l}\text { Average recovery } \\
(\%)\end{array}$ & $\begin{array}{l}\text { MASE MDL } \\
\left(\mathrm{ng} \mathrm{g}^{-1}\right)\end{array}$ & $\begin{array}{l}\text { Average recovery } \\
(\%)\end{array}$ & $\log \mathrm{K}_{\mathrm{ow}}$ \\
\hline \multirow[t]{6}{*}{ Androgens } & Testosterone & 16.0 & 3.2 & 100.9 & 0.07 & 110.7 & $3.179 \pm 0.27$ \\
\hline & 11-Ketotestosterone & 16.2 & 3.4 & 116.6 & 0.09 & 103.6 & $1.296 \pm 0.47$ \\
\hline & 4-androstenedione & 15.2 & 1.3 & 70.2 & 0.12 & 56.1 & $2.717 \pm 0.34$ \\
\hline & Androsterone & 48.6 & 2.4 & 94.3 & 0.34 & 51.8 & $3.932 \pm 0.32$ \\
\hline & $17 \alpha$-trenbolone & 9.4 & 3.2 & 85.4 & 0.16 & 109.9 & $2.316 \pm 0.35$ \\
\hline & $17 \beta$-trenbolone & 18.2 & 4.5 & 93.9 & 0.29 & 121.1 & $2.316 \pm 0.35$ \\
\hline \multirow[t]{4}{*}{ Mycotoxins } & $\alpha$-zearalanol & 33.3 & 9.0 & 82.6 & 0.54 & 135.7 & $3.859 \pm 0.50$ \\
\hline & $\beta$-zearalanol & 33.5 & 6.9 & 195.1 & 0.59 & 61.0 & $3.859 \pm 0.50$ \\
\hline & $\alpha$-zearalenol & 43.6 & 2.0 & 41.5 & 0.71 & 81.8 & $4.168 \pm 0.79$ \\
\hline & $\beta$-zearalenol & 37.6 & 4.0 & 115.4 & 0.58 & 109.6 & $4.168 \pm 0.79$ \\
\hline \multirow[t]{4}{*}{ Estrogens } & $17 \alpha$-estradiol & 21.0 & 2.7 & 28.0 & 0.18 & 87.2 & $4.146 \pm 0.25$ \\
\hline & $17 \beta$-estradiol & 23.7 & 4.2 & 55.6 & 0.52 & 77.2 & $4.146 \pm 0.25$ \\
\hline & Estrone & 35.1 & 4.9 & 88.8 & 0.60 & 110.8 & $3.624 \pm 0.36$ \\
\hline & Estriol & 62.5 & 7.5 & 69.4 & 1.87 & 185.5 & $2.527 \pm 0.28$ \\
\hline \multirow[t]{3}{*}{ Progestagens } & Melengestrol Acetate & 13.4 & 2.8 & 59.5 & 0.2 & 71.1 & $4.206 \pm 0.42$ \\
\hline & Progesterone & 21.0 & 2.7 & 72.7 & 0.26 & 50.9 & $3.827 \pm 0.28$ \\
\hline & $17 \alpha$-hydroxyprogesterone & 26.6 & 3.6 & 95.0 & 0.22 & 85.4 & $3.040 \pm 0.36$ \\
\hline
\end{tabular}

Spiked analyte concentrations were $5 \mathrm{ng} \mathrm{L}^{-1}$ for on-line SPE and $0.5 \mathrm{ng} \mathrm{g}^{-1}$ for test soil.

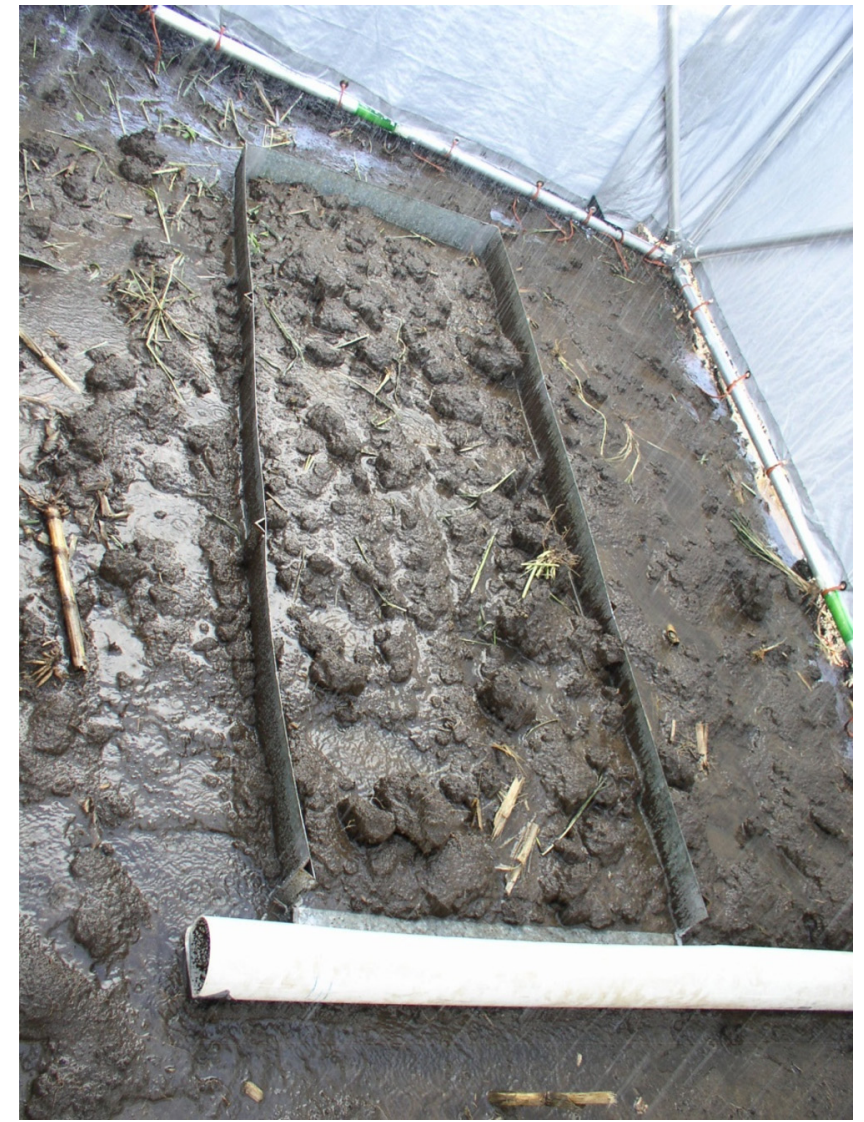

Fig. 2. Field runoff plot boundaries with runoff collection tube.

age recoveries for on-line SPE and MASE for hormones and metabolites are given in Table 2. A detailed description of the analytical procedures can be found in Snow et al. [34]. Calibration for the on-line SPE uses aqueous calibration standards prepared and analyzed as the same time as each batch of 20 samples. Quality controls prepared analyzed with every batch of 20 samples includes a method blank, fortified blank, laboratory duplicate, and fortified matrix (field) sample. All field and quality controls are spiked with internal standards ( ${ }^{13} \mathrm{C} 6$ - estradiol and d5-testosterone) and a known concentration of $17 \alpha$-methyltestosterone used as a measure of extraction efficiency and to monitor for any matrix effects. Analyte recovery in laboratory fortified blanks analyzed at the same time as the rainfall simulation samples ranged from 76 to $118 \%$ and averaged $98 \pm 33 \%$. Recovery of analytes analyzed in fortified matrix samples (spiked duplicates) ranged from 80 to $147 \%$ and averaged $101 \pm 41 \%$. Laboratory method blanks, spiked only with internal standards and surrogate, were well below method detection limits (Table 2) and generally zero. Recovery of the methyltestosterone surrogate added to all samples and quality controls averaged $117.5 \pm 42.9 \%$. Details of the manure analysis and quality controls are reported in Bartelt-Hunt et al. [15].

Concentrations of seventeen steroid hormones or metabolites were quantified and recorded for each manure and runoff sample. Three naturally occurring hormones are commonly used as implants in beef cattle: $17 \beta$-estradiol, testosterone, and progesterone. Three estrogens, $17 \alpha$-estradiol, estrone, and estriol, are all metabolites of $17 \beta$-estradiol; 11-ketotestosterone, 4 -androstenedione, and androsterone are the metabolites of testosterone; and $17 \alpha$-hydroxyprogesterone is a metabolite of progesterone. The semi-synthetic non-steroidal estrogen- zeranol $(\alpha$-zearalanol) is a resorcylic acid lactone and can be derived from zearalenone, and subsequently form $\beta$-zearalanol, $\alpha$-zearalenol, and $\beta$-zearalenol. Trenbolone acetate (TBA), a synthetic anabolic, is used as single or in combination with the natural hormones as implants [35] and is metabolized to form either $17 \alpha$ - or $17 \beta$-trenbolone in vivo. Additionally, a synthetic progestagen, melengestrol acetate (MGA), is used as feed additive to the daily ration of the feedlot cattle.

\subsection{Statistical analysis}

Statistical Analysis Software [36] was used to determine the impact of tillage and manure on rainfall and runoff volume between the two simulations by using PROC GLIMMIX. Rainfall simulation timing (1 DAT and $30 \mathrm{DAT}$ ), tillage (DK, MP, and NT), and manure management ( $C$ and $S$ ) were used in the model statement and replication, replication $\times$ tillage and replication $\times$ tillage $\times$ manure were used in random statement. The least significance difference (LSD) 


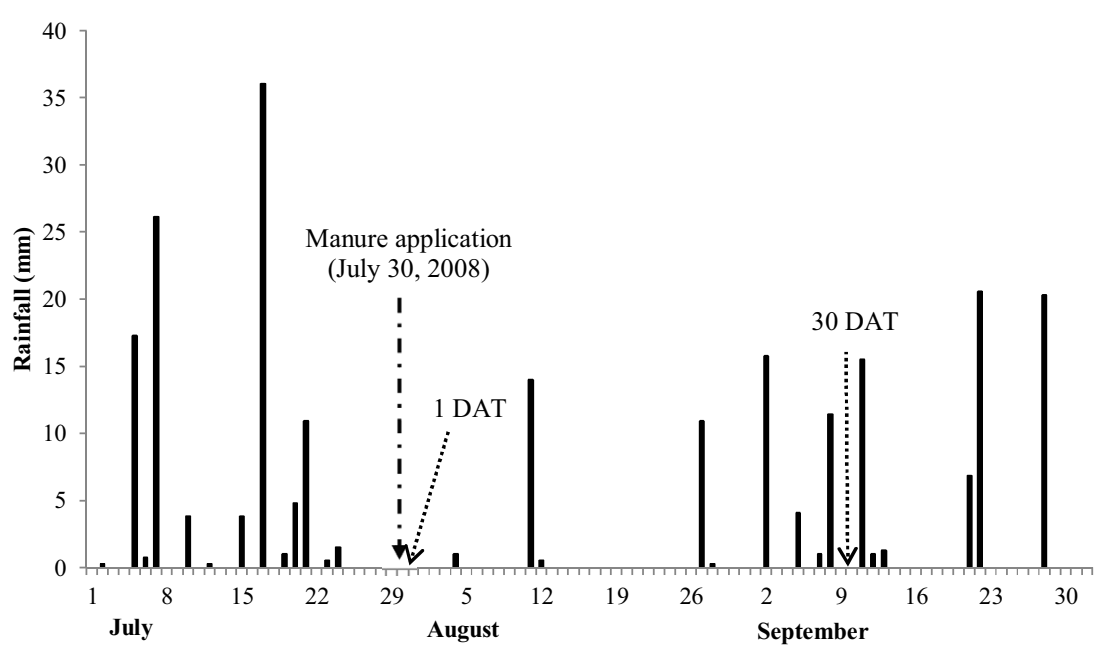

Fig. 3. Natural rainfall events during the time leading up to and between the 1 DAT and 30 DAT sampling events in the study area in 2008 .

$\square 1 \mathrm{DAT} \quad \mathbf{\square} 30 \mathrm{DAT}$

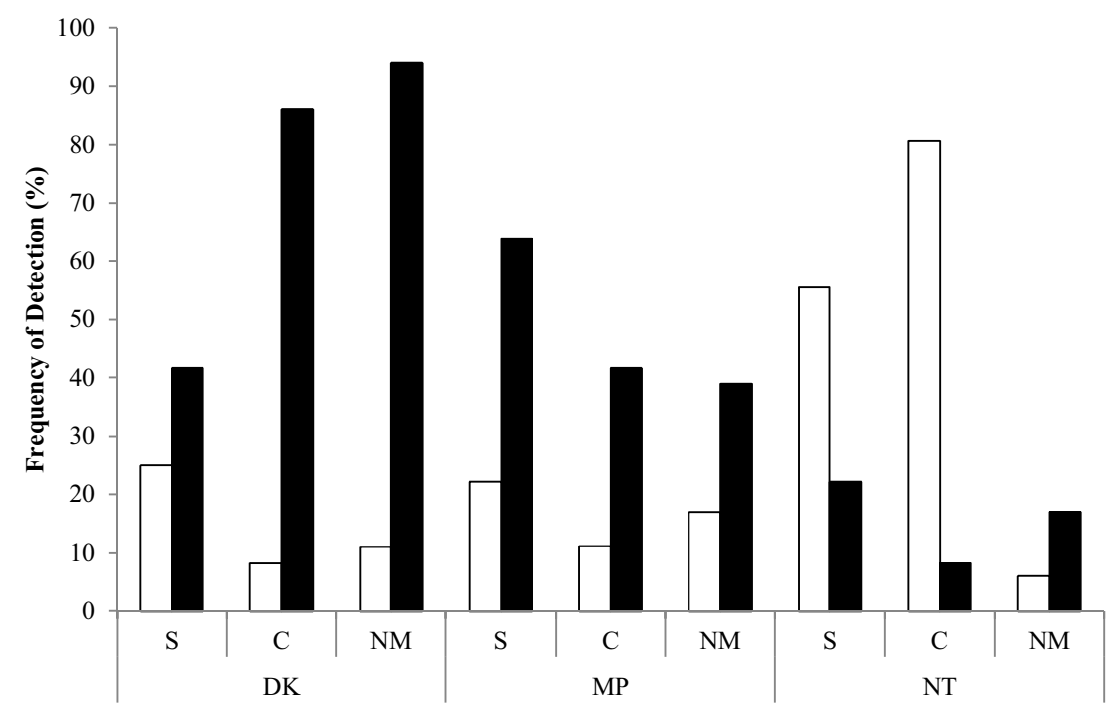

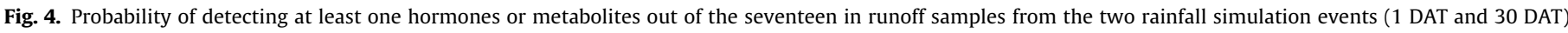

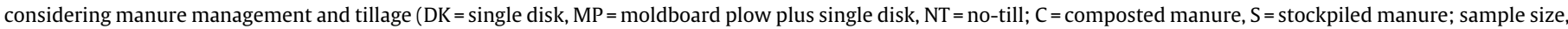
$\mathrm{n}=36 ; \mathrm{NM}=$ control/no-manure, $\mathrm{n}=18$ ).

method was used for pairwise comparison among the treatments with the level of significance being set at $\alpha=0.05$.

\section{Results and discussion}

\subsection{Manure analysis}

Twelve of the seventeen hormones or metabolites were detected in the composted or stockpiled manure samples from hormone treated and untreated animals prior to land application (Table 3). The summed total concentrations of hormones and metabolites in the hormone treated stockpiled (ST) and composted (CT) manure were $26.7 \mathrm{ng} \mathrm{g}^{-1}$ and $14.7 \mathrm{ng} \mathrm{g}^{-1}$ (dry weight), respectively, and they were slightly greater than the summed total concentrations of $24.7 \mathrm{ng} \mathrm{g}^{-1}$ and $9.9 \mathrm{ngg}^{-1}$ (dry weight), respectively in the untreated stockpiled (SU) and composted (CU) manure. The average concentration in composted $(\mathrm{CT}+\mathrm{CU})$ manure (12.3 $\mathrm{ng} \mathrm{g}^{-1} \mathrm{dw}$ ) was less than half of the stockpiled $(\mathrm{ST}+\mathrm{SU})$ manure $\left(25.7 \mathrm{ng} \mathrm{g}^{-1} \mathrm{dw}\right)$, whereas the average concentrations of hormone treated $(\mathrm{ST}+\mathrm{CT})$ manure $\left(20.7 \mathrm{ng} \mathrm{g}^{-1} \mathrm{dw}\right)$ were marginally greater than untreated cattle manure ( $\mathrm{SU}+\mathrm{CU})$ concentration $\left(17.3 \mathrm{ng} \mathrm{g}^{-1} \mathrm{dw}\right)$. The reduction of hormone concentration in composted manure from treated and untreated animals is consistent with the findings of several other studies where the authors found that composting can be an effective alternative to stockpiling the manure $[15,37,38]$.

The three most commonly detected hormones or metabolites were 4 -androstenedione $\left(1.8-6.8 \mathrm{ng} \mathrm{g}^{-1}\right)$, estrone (3.7-5.4 $\left.\mathrm{ng} \mathrm{g}^{-1}\right)$, and progesterone (0.7-4.1 $\left.\mathrm{ng} \mathrm{g}^{-1}\right)$ in both composted and stockpiled manure, irrespective of hormone treatments to cattle (Table 3). Bartelt-Hunt et al. [14] analyzed fresh manure samples from the feeding pen surface, and reported that 4-androsterone, estrone, and progesterone were the most commonly found hormones or metabolites in fresh manure at concentrations ranging from 1.1 to $1.5,11$ to 25.6 , and 0.84 to $7.7 \mathrm{ng} \mathrm{g}^{-1}$, respectively. Considering the time difference between the manure collections from pen to the time before field application, it can be expected that some forms of hormones or metabolites are more persistent in the environment than others. After storage, fewer samples contained detectable residues of exogenous hormones ( $\alpha$-zearalenol 


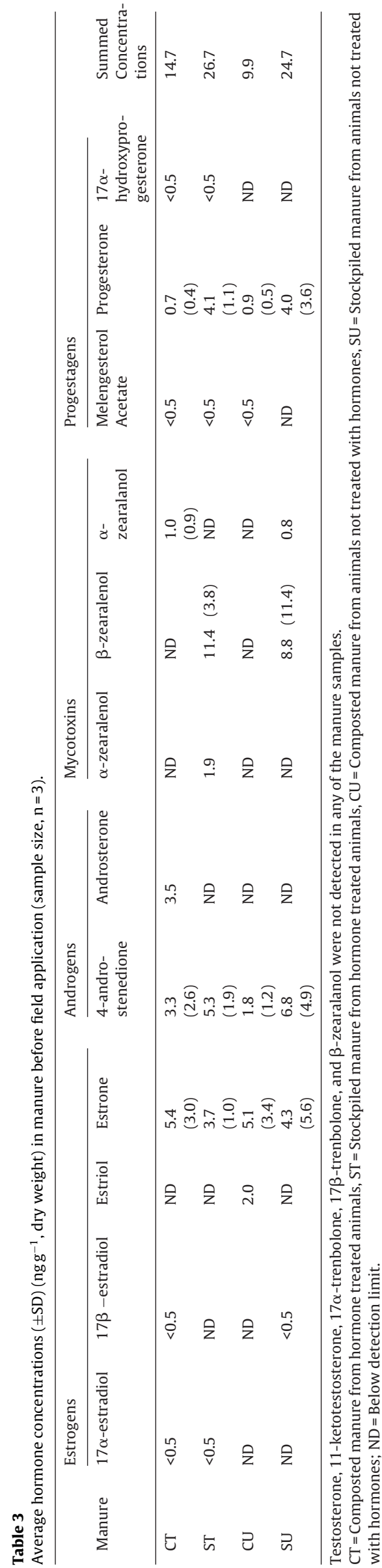

or melengestrol acetate) and only from treated animals, and some of the detections were close to or below the method quantification limit (Tables 2 and 3).

The implant compound, $\alpha$-zearalanol (zeranol) and its metabolite $\beta$-zearalenol, were detected in manure collected from both hormone treated or untreated animals and from control plots. The presence of these compounds in manure collected from untreated animals or control plots may be attributed to formation of Fusarium mold that may have been present in corn silage or grain included in feed rations $[14,39,40]$. Lack of detections of synthetic hormones in manure is consistent with previous studies and may be attributed to rapid degradation during composting $[13,41]$.

\subsection{Frequency of detection in runoff samples}

Since there was no statistically significant difference in hormone concentrations in manure from treated and untreated animals in either composted ( 14.7 vs $9.9 \mathrm{ng} \mathrm{g}^{-1}$ ) or stockpiled (26.7 vs $24.7 \mathrm{ng} \mathrm{g}^{-1}$ ) manure before field application, the results were summarized averaging the hormone treatment effects based on manure management (e.g. composting and stockpiling only). The number of runoff samples testing positive for steroid hormone was very low and inconsistent between the two rainfall simulation events. In addition, because of the low frequency of detections, it was not possible to observe temporal concentration variations in the samples collected at $5 \mathrm{~min}$ intervals until $30 \mathrm{~min}$ after runoff initiation. Thus, the results of sampling and analysis are reported as the frequency of detection and range of concentrations using box and whisker plots. The probability of detecting any single hormone or metabolite is presented in Fig. 4 and it varied from $8 \%$ to $86 \%$ in runoff samples under any particular tillage and manure treatment $(n=36)$. However, there was some detections of hormones or metabolites from the control (NM) plots $(n=18)$ under each tillage treatment which indicated the ubiquitous presence of these tracer compounds.

Comparison of the frequency of detection among the two rainfall simulation events found fewer hormone detections in runoff samples in the DK and MP tillage from both composted and stockpiled manure applied plots during the 1 DAT rainfall simulation (Fig. 4). This is likely due to the incorporation of the manure during the tillage treatments. In contrast, more frequent detections were recorded in runoff samples from NT tillage during the 1 DAT rainfall simulation in both manure applied plots as the applied manure was not incorporated for the NT treatment and the applied rainfall was free to detach and transport the manure and hormones in surface runoff.

The highest frequency of detection in runoff from the 30 DAT rainfall simulation was recorded from DK and MP tillage treatments when compared to the NT treatment. This difference could be explained by more transformation of hormones or metabolites in the surface applied manure, and greater persistence after incorporation. The greater frequency of detection recorded in runoff from soils receiving composted manure under DK tillage at 30 DAT and NT tillage at 1 DAT was unexpected since the applied hormone concentration in stockpiled manure was lower than the composted manure. More frequent occurrence could be associated with microbial transformation of conjugated hormones, breakdown, and release of protein-associated hormones, and the strong adsorptiondesorption characteristics of these compounds as observed by others [42-44].

The overall low frequency of detection of hormones in surface runoff samples was also observed in previous studies [14,20,45]. Mansell et al. [20] estimated that $37 \%$ to $99 \%$ of hormones can be associated with the organic matter of the suspended sediment depending on the dissolved organic carbon in runoff, whereas the current study analyzed the liquid potion of the runoff samples after filtering the suspended sediment. However, the increase in 
Table 4

Linear equilibrium sorption coefficients $\left(K_{d}\right)$ for commonly found hormones and metabolites.

\begin{tabular}{|c|c|c|}
\hline Hormone/Metabolite & $\mathrm{K}_{\mathrm{d}}\left(\mathrm{L} \mathrm{kg}^{-1}\right)$ & References \\
\hline $17 \alpha$-estradiol & 22.8 & [58] \\
\hline $\begin{array}{l}17 \beta- \\
\text { estradiol }\end{array}$ & $\begin{array}{l}170.48 \\
83.2 \\
26.2 \\
83.2 \\
32.6 \\
50\end{array}$ & $\begin{array}{l}{[59]} \\
{[60]} \\
{[61]} \\
{[62]} \\
{[58]} \\
{[63]}\end{array}$ \\
\hline Estrone & $\begin{array}{l}48.1 \\
17.8 \\
48.1 \\
54\end{array}$ & $\begin{array}{l}{[60]} \\
{[61]} \\
{[62]} \\
{[63]}\end{array}$ \\
\hline Estriol & 16 & [63] \\
\hline Testosterone & $\begin{array}{l}79.9 \\
42.7 \\
42.7\end{array}$ & $\begin{array}{l}{[27]} \\
{[60]} \\
{[62]}\end{array}$ \\
\hline $\begin{array}{l}\text { Androstenedion } \\
17 \alpha \text {-trenbolone } \\
17 \beta \text {-trenbolone } \\
\text { MGA } \\
\alpha \text {-zearalanol }\end{array}$ & $\begin{array}{l}142 \\
7.5 \\
15.4 \\
63.9 \\
14.5\end{array}$ & $\begin{array}{l}{[60]} \\
{[64]} \\
{[64]} \\
{[61]} \\
{[61]}\end{array}$ \\
\hline
\end{tabular}

frequency of detections at 30 DAT agrees with results from the previous study by Mansell et al. [20].

Overall, among the hormones and metabolites, estrone and estriol were the two most commonly detected metabolites, occurring in $9 \%$ of the runoff samples $(n=216,30$ DAT) irrespective of tillage and manure treatments (data not shown). Among synthetic hormones or metabolites, MGA, $17 \alpha$-trenbolone, or zearanol metabolites were detected in $3 \%$ of the runoff samples from the 1 DAT sampling event $(n=216)$ and $16 \%$ of the runoff samples detected synthetic hormone during the 30 DAT sampling event $(n=216)$. The high detection of four zeranol metabolites in 30 DAT samples could be produced by the commonly found fungi in the row-cropped fields. Bartelt-Hunt et al. [14] found the presence of estrone in $29 \%$ samples but only $2 \%$ detection of $17 \beta$-trenbolone and $6 \%$ detection of MGA in runoff samples generated directly from feedlot surface; whereas there was no presence of $17 \alpha-$ trenbolone when $n=50$. From a field study in Indiana, Gall et al. [45] reported the detection of estrone in $10 \%$ to $41 \%$ of water samples $(n=190-589)$ from tile drains and $36 \%$ to $55 \%$ of water samples $(\mathrm{n}=372-683)$ from drainage ditches. In contrast to the other natural hormones, they reported the low detections of $17 \alpha$-trenbolone (maximum 5.6\% when $\mathrm{n}=589$ ) and $17 \beta$-trenbolone (maximum $2 \%$ when $n=508$ ) in water samples from the subsurface tile drains and drainage ditches, respectively. Thus, low detection of synthetic hormone of this study agrees with the findings of the previous studies.

The presence of hormones or metabolites in runoff are primarily governed by their sorption characteristics in soil-water system. The values of linear sorption co-efficient $\left(\mathrm{K}_{\mathrm{d}}\right)$ of commonly studied hormones or metabolites in the similar soil are reported in Table 4. The compounds with higher $\mathrm{K}_{\mathrm{d}}$ values showed greater sorption affinity with soil. Thus, $17 \beta$-estradiol, testosterone, androstenedione, and MGA are less likely to be detected in dissolved phase of runoff compared to sediment bound portion. On the contrary, sorption is inversely proportional to desorption. Ma et al. [19] studied the desorption capacity of testosterone in the same soil and found less than $10 \%$ desorption after first cycle of analysis which indicated low desorption of testosterone in the soil-water systems especially if it was sorbed on top soil or on a soil with high clay content. A greater OM content caused stronger binding of testosterone with soil and resulted less desorption. The similar phenomenon is true for other hormones and metabolites with higher linear partitioning co-efficient values in OM enriched soil.

\subsection{Bulk steroid hormone transport}

The concentration of hormones and metabolites in runoff samples from the two rainfall simulation events under different tillage and manure treatments are presented in Figs. 5-7 . Thirteen out of seventeen hormones or metabolites were detected in the runoff samples above the method detection limit at least once. The synthetic androgen metabolite $17 \beta$-trenbolone was not detected in any runoff samples from any simulation event. Additionally, $\alpha$ zearalenol, $\beta$-zearalenol, and $17 \alpha$-estradiol were not detected in any of the runoff samples from simulation at 1 DAT and 11ketotestosterone was not detected during the 30 DAT rainfall simulation.

In the DK tillage plots when stockpiled manure was applied, there were more hormone detections in runoff from the 30 DAT rainfall simulation event compared to the 1 DAT (Fig. 5a). Estrone was the most commonly detected metabolite during the 1 DAT simulation with a concentration range of $6-33 \mathrm{ng} \mathrm{L}^{-1}$. Estrone was also the prominent form of estrogen in composted and stockpiled manure (Table 3). Lafrance and Caron [46] found the concentration of estrone in stream samples up to $58.1 \mathrm{ng} \mathrm{L}^{-1}$ from seven sampling locations $24 \mathrm{~h}$ after manure application. During the 30 DAT rainfall simulation, 4 -anderostenedione and $\alpha$-zearalanol were the two most commonly detected hormones or metabolites with concentrations ranging from 6 to $8 \mathrm{ng} \mathrm{L}^{-1}$ and 10 to $34 \mathrm{ng} \mathrm{L}^{-1}$, respectively. Among the androgens, 4 -anderostenedione was the most dominant form in both applied composted and stockpiled manure (Table 3).

Runoff from the composted manure applied plots in DK tillage, had a greater frequency of detections in runoff from the 30 DAT event compared to the 1 DAT event (Fig. 5b). Runoff from 30 DAT plots recorded $\beta$-zearalanol more frequently and at concentrations ranging from 8 to $25 \mathrm{ng} \mathrm{L}^{-1}$, while $17 \beta$-estradiol concentrations ranged from 36 to $189 \mathrm{ng} \mathrm{L}^{-1}$.

Overall, steroid hormones were more frequently detected in runoff from the MP and DK tillage plots for the 30 DAT event compared to the 1 DAT event. Estrone was most commonly detected in runoff from the MP tillage plots treated with either stockpiled or composted manure. Concentration of estrone ranged from 6 to $202 \mathrm{ng} \mathrm{L}^{-1}$ and 15 to $59 \mathrm{ng} \mathrm{L}^{-1}$, respectively during the 30 DAT sampling event (Fig. 6a). Androsterone (20-164 $\mathrm{ng} \mathrm{L}^{-1}$ ) was the second most frequently detected compound in runoff from the 1 DAT sampling event when plots were treated with stockpiled manure. Melengestrol acetate was detected in samples during the 1 DAT sampling event at concentrations ranging from 5 to $19 \mathrm{ng} \mathrm{L}^{-1}$ and 6 to $52 \mathrm{ng} \mathrm{L}^{-1}$, respectively from stockpiled and composted manure applied plots (Fig. 6b).

Under surface application (NT tillage) for both stockpiled and composted manure, greater steroid hormone and metabolite detections were recorded in runoff at 1 DAT. Progesterone was the most commonly detected steroid hormone at concentrations ranging from 6 to $58 \mathrm{ng} \mathrm{L}^{-1}$ and 7 to $62 \mathrm{ng} \mathrm{L}^{-1}$ in runoff from stockpiled and composted manure treated soils, respectively (Fig. 7a and b). Other steroids detected in 1 DAT simulation event runoff samples included testosterone (6-84 $\mathrm{ng} \mathrm{L}^{-1}$ ), $17 \beta$-estradiol (15-39 $\mathrm{ng} \mathrm{L}^{-1}$ ), and estrone (12-51 $\left.\mathrm{ng} \mathrm{L}^{-1}\right)$. By comparison, estrone concentrations ranged between $31-80 \mathrm{ng} \mathrm{L}^{-1}$ from the stockpiled manure applied plots 30 DAT.

During 30 DAT, there was some detections of naturally found hormones and metabolites from a control (NM) plots under the DK tillage and it was suspected that might have some wildlife source (Fig. 4 \& Table 5). Traces of other natural hormones were also observed from other two tillage treatments. The presence of 


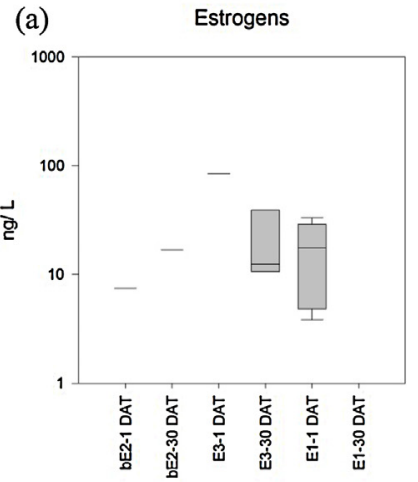

(b)

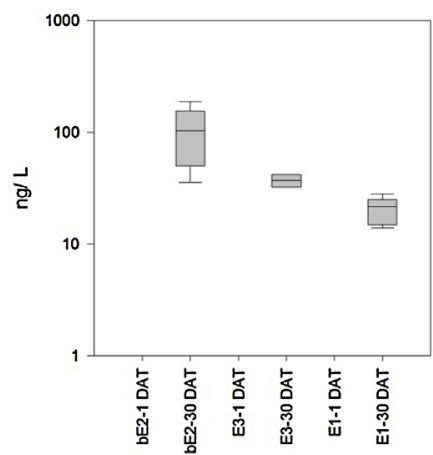

Androgens

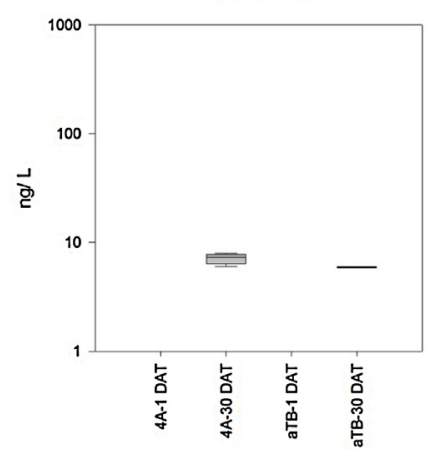

Androgens

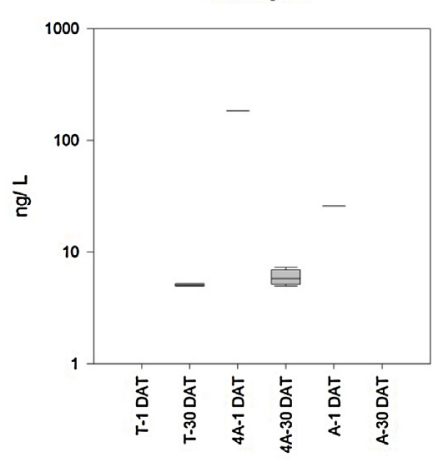

Progestagens
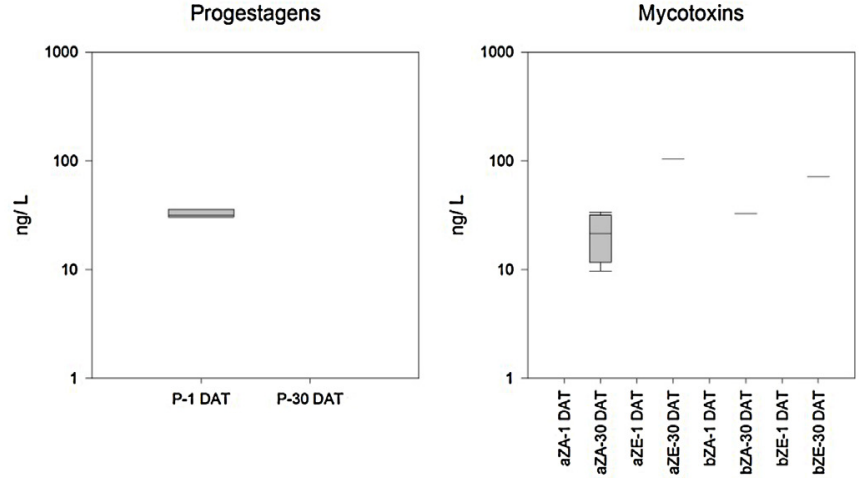

Progestagens

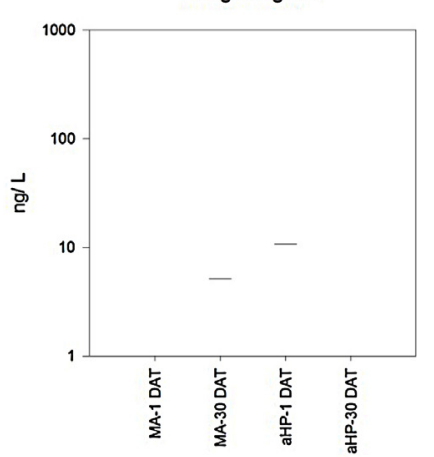

Mycotoxins

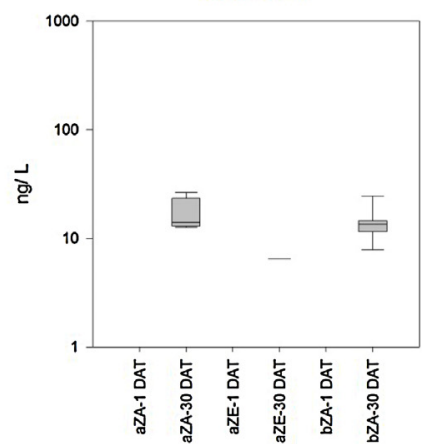

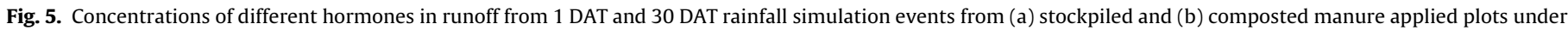
disk tillage (sample size, $\mathrm{n}=36$ ).

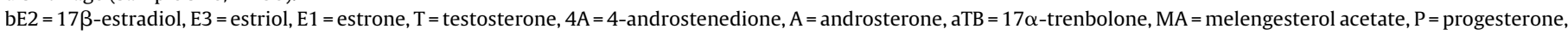

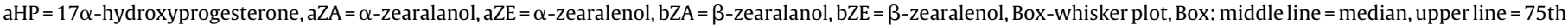
percentile, lower line $=25$ th percentile; Whisker: upper $=$ maximum, lower $=$ minimum

Table 5

Maximum concentrations ( $\mathrm{ng} \mathrm{L}^{-1}$ ) of hormones or metabolites detected in the runoff samples from control plots ( $\mathrm{n}=18$ ).

\begin{tabular}{|c|c|c|c|c|}
\hline Tillage & $1 \mathrm{DAT}$ & & 30 DAT & \\
\hline \multirow[t]{9}{*}{ DK } & Testosterone & 22.6 & Testosterone & 20.3 \\
\hline & & & 4-androstenedione & 27.8 \\
\hline & & & $\alpha$-zearalenol & 325.5 \\
\hline & & & $\beta$-zearalanol & 32.2 \\
\hline & & & $17 \alpha$-estradiol & 10.4 \\
\hline & & & $17 \beta$-estradiol & 20.2 \\
\hline & & & Estrone & 39.9 \\
\hline & & & Progesterone & 6.6 \\
\hline & & & $17 \alpha$-hydroxyprogesterone & 5 \\
\hline \multirow[t]{3}{*}{ MP } & Androsterone & 11.3 & $\alpha$-zearalanol & 20.1 \\
\hline & Estriol & 40.9 & Estriol & 14.3 \\
\hline & $17 \alpha$-hydroxyprogesterone & 6.1 & Estrone & 8.7 \\
\hline NT & $\beta$-zearalanol & 5.1 & $\beta$-zearalanol & 29.6 \\
\hline
\end{tabular}

mycotoxins from all the control plots was associated with the relationship of Fusarium metabolites with corn.

The transport mechanism of hormone in runoff is governed by the partitioning between sediment-associated and aqueousfraction and is the underlying reason for the presence of hormones in surface runoff from agricultural fields. Sangster et al. [47] studied the sorption of $17 \beta$-estradiol, estrone, progesterone, and testosterone in silty loam sediments and concluded that at low aqueous concentrations ( $1 \mathrm{ng} / \mathrm{L}$ ) up to $93 \%$ of sediment associated hormone found in the fine fraction and the smaller particles have a greater tendency to be suspended in and move with the water column. The low frequency of detection in our study might be correlated with the phenomenon as the reported concentrations are based on analyzing the aqueous portion of samples. However, Qu et al. [18] examined the fate of metabolites from synthetic growth promoters (trenbolone acetate, melengestrol acetate, and zeranol) in sterilized soil. They found that in organic-rich soil the extent and reversibility of sorption did not generally correlate with compound hydrophobicity ( $\mathrm{K}_{\mathrm{ow}}$ values), and it is likely that specific binding interactions (hydrogen bonding through hydroxyl groups for the trenbolone and melengestrol families) can also contribute to sorption. They also showed that soils with lower organic carbon contents (1-5.9\% OC) can support sorption occurring in parallel with surface reaction on inorganic mineral phases. Subsequent experiments with pure mineral phases (iron, silica, and manganese oxides) suggested that growth promoters are prone to mineral-promoted oxidation, hydrolysis, and/or nucleophilic $\left(\mathrm{H}_{2} \mathrm{O}\right.$ or $\left.\mathrm{OH}-\right)$ addition reactions in their study. Additionally, the physio-chemical dynamics of the soil- 
(a)

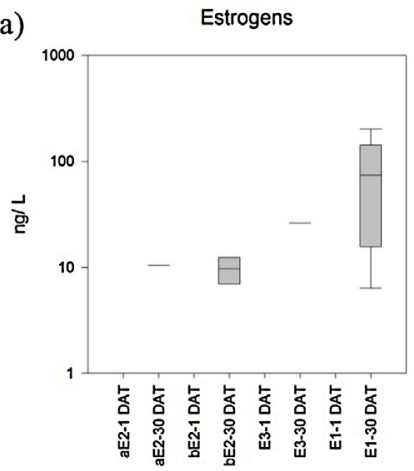

(b)

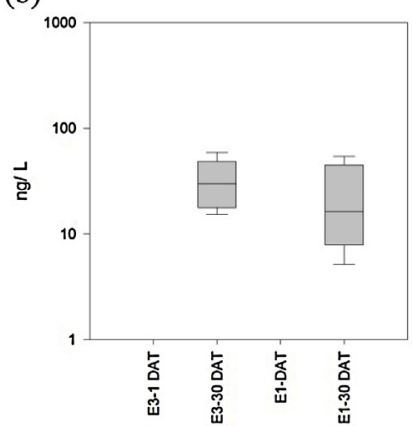

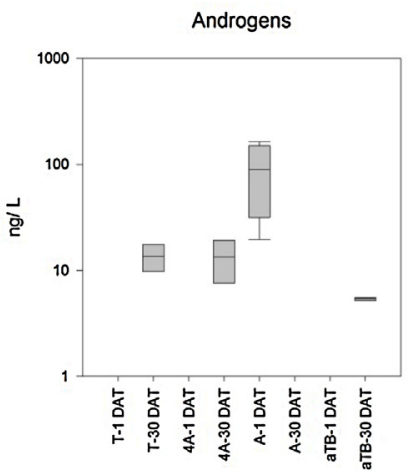

Androgens

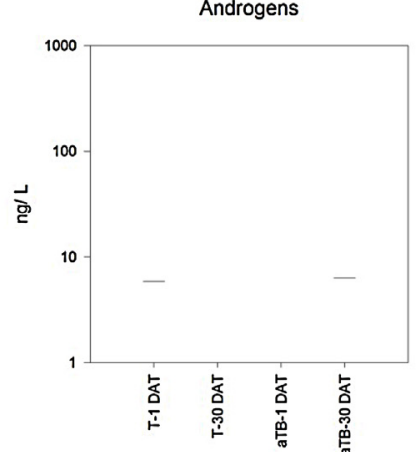

Progestagens

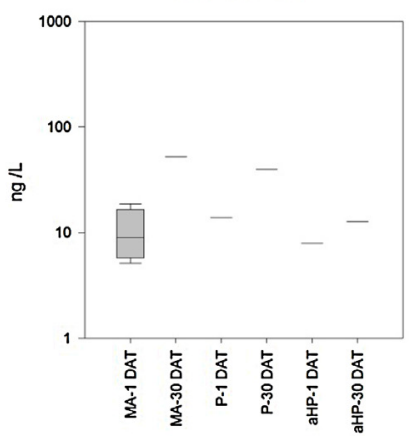

Progestagens

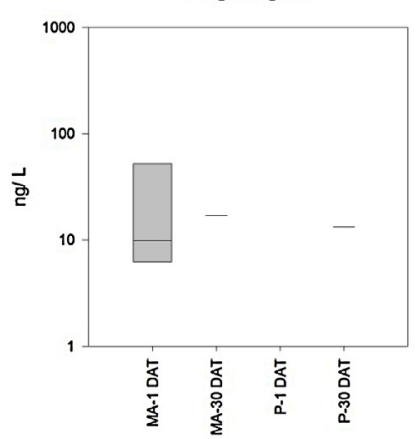

Mycotoxins

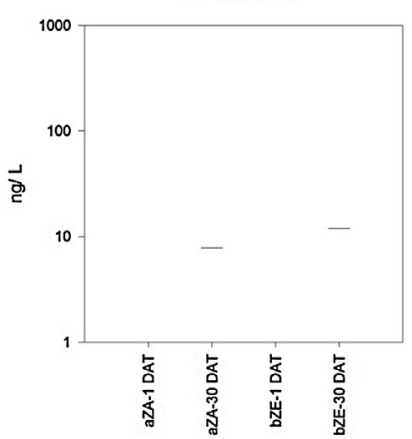

Mycotoxins

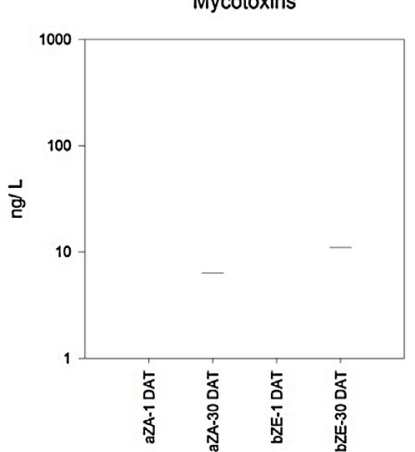

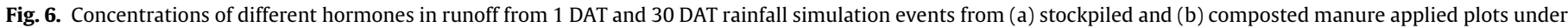
moldboard plow plus disk tillage (sample size, $n=36$ ).

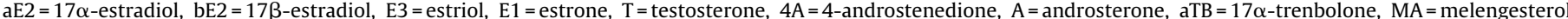

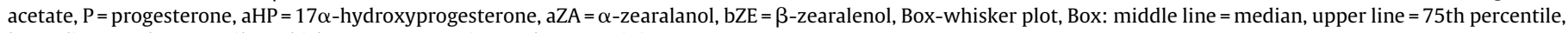
lower line $=25$ th percentile; Whisker: upper $=$ maximum, lower $=$ minimum

(a)

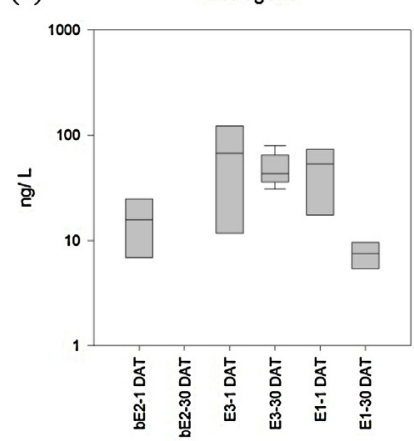

(b)

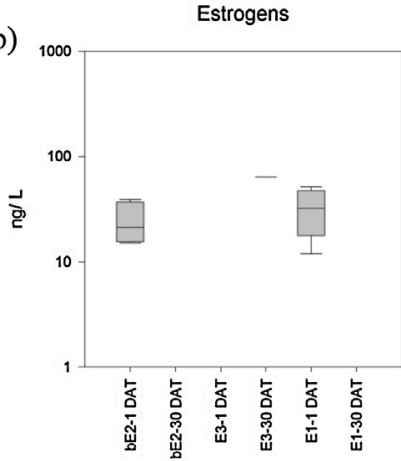

Androgens

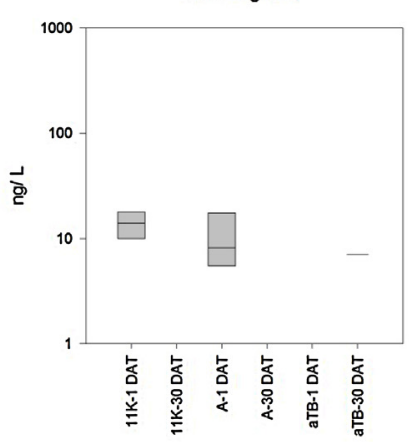

Androgens

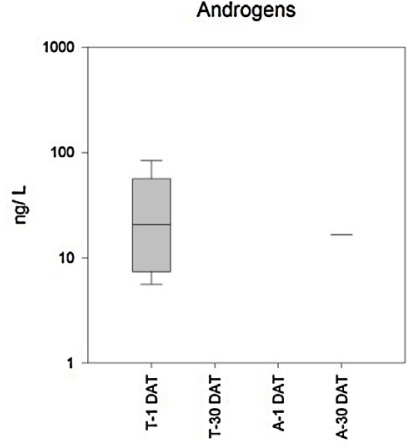

Progestagens
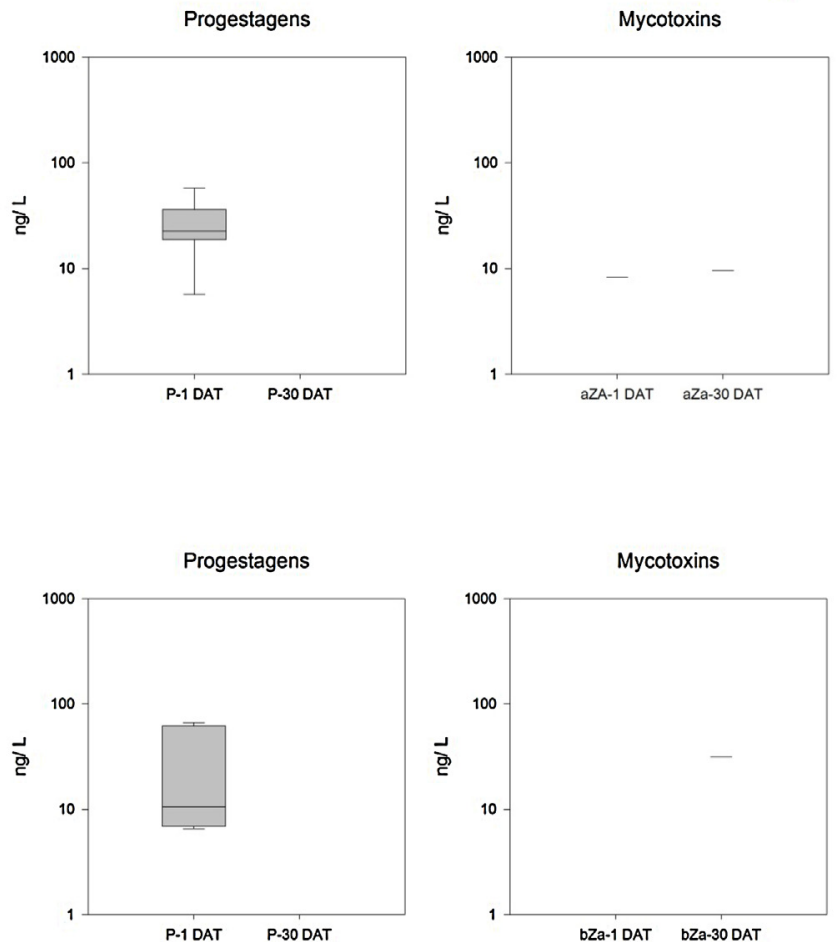

Mycotoxins

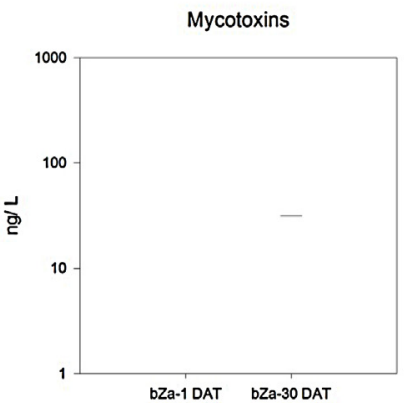

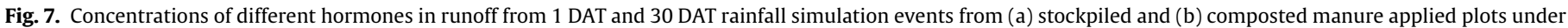
no-till tillage (sample size, $n=36$ ).

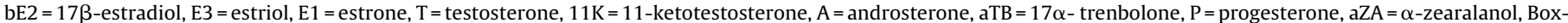
whisker plot, Box: middle line = median, upper line = 75th percentile, lower line $=25$ th percentile; Whisker: upper $=$ maximum, lower $=$ minimum 
water systems and non-equilibrium condition of hormones after field application play an important role.

Estrogens and estrogenic substances were the most commonly detected compounds in runoff from all treatments. Environmentally significant concentrations of estrogens were most closely associated with estrone and estriol, both metabolites of $17 \beta$ estradiol. According to the Environment Agency of the United Kingdom, the Predicted-No-Effect-Concentrations (PNEC) was $1 \mathrm{ng} \mathrm{L}^{-1}$ for $17 \beta$-estradiol and $3-5 \mathrm{ng} \mathrm{L}^{-1}$ for estrone, while no PNEC is available for estriol [48]. Barel-Cohen et al. [49] reported that $10 \mathrm{ng} \mathrm{L}^{-1}$ as the Lowest Observable Effect Level (LOEL) for total estrogen (17 $\beta$ - estradiol + estrone). The results of this study are similar to previous reports by Mansell et al. [20] and Yang et al. [50]. DeLaune and Moore [51] also showed that manure type, application rate, and time until the first runoff event after manure application can affect the transport of steroid hormones to surface water. Gall et al. [45] reported that estrone (1.3-40 $\left.\mathrm{ng} \mathrm{L}^{-1}\right)$, testosterone (2.4-50.5 $\left.\mathrm{ng} \mathrm{L}^{-1}\right)$, and androstenedione (1.6-16.6 $\mathrm{ng} \mathrm{L}^{-1}$ ) were the most frequently detected steroid hormones in runoff from tile-drained field treated with manure at concentrations (5.0-210.9 $\mathrm{ng} \mathrm{L}^{-1}, 5.0-83.9 \mathrm{ng} \mathrm{L}^{-1}$, and 5-84.5 $\mathrm{ng} \mathrm{L}^{-1}$, respectively) comparable to the present study. Zhang et al. [52] also reported the presence of estrogens (average concentration $3.35 \mathrm{ng} \mathrm{L}^{-1}$ ), androgens $\left(14.0 \mathrm{ng} \mathrm{L}^{-1}\right)$, and progestogen $\left(0.82 \mathrm{ng} \mathrm{L}^{-1}\right)$ in surface drainage from intensive vegetable cultivated field. The results of our study are consistent with the reported results. The increasing concentrations of Fusarium metabolites in runoff samples during 30 DAT rainfall simulation may be explained by the in-situ fungal action from the Fusarium genus which is widely distributed in soil and associated with corn plants [14,23,53]. These fungi occur in corn or barley and have been found to naturally produce mycotoxins like $\alpha$-zearalanol and its metabolites.

\subsection{Effect of tillage and runoff potential}

During both rainfall simulation events, rainfall intensity was maintained at $70 \mathrm{~mm} \mathrm{~h}^{-1}$, and Table 6 shows the amount of rainfall, runoff, and runoff initiation time to generate 30 min equivalent runoff from different treatment plots. The average amount of rainfall required to generate 30 min of runoff was similar from different tillage treatments irrespective of manure types in $1 \mathrm{DAT}$; however, at 30 DAT, it varied among the tillage treatments. There was no significant difference in runoff initiation time among the treatment plots during the 1 DAT rainfall event (Table 6). This was expected since newly tilled soils (DK and MP) typically exhibit greater porosity and initial infiltration capacity, though compaction tends to even out differences after 30 days at the second rainfall simulation event [54]. The amount of simulated rainfall needed to initiate runoff was significantly greater for NT soils $(139 \mathrm{~mm}$ and $227 \mathrm{~mm}$ in stockpiled and composted manure applied plots, respectively) during the 30 DAT event compared to MP (62 mm and $61 \mathrm{~mm}$, respectively) and DK (99 $\mathrm{mm}$ and $97 \mathrm{~mm}$, respectively) tillage treatments. During 30 DAT, runoff initiation times from the NT plots were also significantly higher compared to DK and MP plots. Previous studies have reported a relation between total surface runoff and hormone losses from crop fields [55,56]. In the current study, the frequency of detections from the stockpiled and composted manure applied plots were positively related with runoff volume from the NT treatment where greater runoff volume resulted in greater frequency of detection during the two sampling events, though in general greater runoff volume was not associated with the tilled soils. Dutta et al. [56] found that runoff from no-till resulted in less estrogen export in surface runoff in comparison to other tillage treatments, and the mass of estrogen export was closely related to the depth of rainfall per event. They also found that mass export of estrogens in surface runoff from reduced tillage was inconsistent among the rainfall events. In a similar study, Jenkins et al. [55] found significantly lower runoff loads of estradiol and testosterone from no-till plots than from conventional tilled plots. The authors attributed the results to lower runoff and greater infiltration rates from the no-till plots when compared with the tilled plots. These studies suggest that tillage to incorporate hormones into the soil may not successfully reduce the movement of manure-borne hormones in runoff. Therefore, the range of incorporation methods as well as manure management methods considering hormone treatment and environmental conditions need to be examined more extensively in order to mitigate the transport of hormones to surface water.

In contrast, Biswas et al. [57] conducted a rainfall simulation study $24 \mathrm{~h}$ after manure application using $17 \alpha$-ethynylestradiol (EE2) applied to manure-treated soil as a surrogate to measure losses from no-till soil. The EE2 and manure were incorporated using a single disk treatment or left on the soil surface using a no-till practice. Rainfall simulations were conducted in the same manner as the current study. Results indicated 96\% less EE2 mass transport from disk tilled plots compared to no-till. The greatest loss of EE2 was 156 and $6 \mathrm{mg} \mathrm{ha}^{-1}$ from no-till and disked plots, respectively. Results from the study showed that a single-pass disk tillage treatment can limit the overland transport of steroid hormones from crop production areas. Overall, the results of current study indicated that tillage might alter the hydrologic characteristics of a row crop field but the short term advantages of tillage are quickly replaced by a long term reduction in soil water infiltration rates and an increased potential for surface runoff when compared with the use of no-till practices. In addition, no-till practices withstand a rainfall event with a greater intensity and duration than tilled fields without generating runoff.

\subsection{Representative mass loss of hormone or metabolite in runoff}

To predict the loss of hormone/metabolite in 30 min runoff during the two rainfall events, the highest detected concentrations of four hormones/metabolites (from the four major categories) were selected in the composted or stockpiled manure. The total mass of an applied hormone in manure from a single runoff plot was determined by multiplying the concertation of a hormone/metabolite in Table 3 with the mass of applied manure. The mass of manure was determined by multiplying the plot area with the manure application rate. The wet weight of manure was adjusted considering the moisture content of manure in Table 1. Similarly, to determine the mass of hormone in $30 \mathrm{~min}$ runoff, the detected concentration of a hormone in runoff was multiplied with the volume of $30 \mathrm{~min}$ runoff. The percent loss of a hormone/metabolite in 30 min runoff was calculated based on the mass in applied manure under each tillage-manure treatment.

Results from the analysis found that less than $10 \%$ mass of the applied hormone was lost through the dissolved phase of runoff from any rainfall events during the experiment (Table 7). Estrone, 4-anderostenedion, progesterone, and $\beta$-zearalenol were selected due to their occurrence at the greatest concentrations in manure from the four major hormone categories of estrogens, androgens, progestagens, and mycotoxins, respectively. The percentage of mass loss in runoff during the two rainfall events is shown in Table 7. Estrone is one of the most commonly reported estrogen metabolites in environment and the losses went up to $1.2 \%$ and $2.8 \%$ in runoff during the 1 DAT and 30 DAT rainfall events, respectively. They have a relatively low sorption equilibrium coefficient $\left(K_{d}\right)$ compared to $17 \beta$-estradiol (Table 4 ) and could be the reason of frequent detection in the environment compared to the other estrogens. Among the androgens, androstenedion is another commonly found metabolite with a very high $K_{d}$ value (Table 4 ). The low occurrence of androstenedione in the dissolved phase of 
Table 6

Summary of hydrological parameters during the two rainfall simulation events.

\begin{tabular}{|c|c|c|c|c|c|c|c|}
\hline \multirow[t]{2}{*}{ Tillage } & \multirow[t]{2}{*}{ Manure } & \multicolumn{2}{|c|}{ Rainfall (mm) } & \multicolumn{2}{|c|}{ Runoff (mm) } & \multicolumn{2}{|c|}{ Runoff initiation time (min) } \\
\hline & & $1 \mathrm{DAT}$ & 30 DAT & $1 \mathrm{DAT}$ & 30 DAT & $1 \mathrm{DAT}$ & 30 DAT \\
\hline \multirow[t]{3}{*}{ DK } & $\mathrm{S}$ & $144^{\mathrm{b}}$ & $99^{\mathrm{cd}}$ & $9^{\mathrm{bcd}}$ & $6^{\text {cdef }}$ & $78^{\mathrm{b}}$ & $45^{\mathrm{bcd}}$ \\
\hline & $\mathrm{C}$ & $109^{\mathrm{bcb}}$ & $97^{\mathrm{cd}}$ & $12^{\mathrm{ab}}$ & $5^{\text {def }}$ & $54^{\mathrm{bc}}$ & $77^{\mathrm{b}}$ \\
\hline & NM & 127 & 148 & 13 & 4 & 43 & 42 \\
\hline \multirow[t]{3}{*}{ MP } & $\mathrm{S}$ & $103^{\mathrm{bcd}}$ & $62^{\mathrm{d}}$ & $11^{\mathrm{abc}}$ & $9^{\text {bcde }}$ & $51^{\text {bcd }}$ & $22^{\mathrm{cd}}$ \\
\hline & $\mathrm{C}$ & $130^{\mathrm{bc}}$ & $61^{\mathrm{d}}$ & $14^{\mathrm{a}}$ & $10^{\mathrm{bc}}$ & $66^{\mathrm{b}}$ & $14^{\mathrm{d}}$ \\
\hline & NM & 160 & 115 & 12 & 8 & 71 & 38 \\
\hline \multirow[t]{3}{*}{ NT } & S & $129^{\mathrm{bc}}$ & $139^{\mathrm{bc}}$ & $10^{\mathrm{abc}}$ & $4^{\mathrm{ef}}$ & $66^{\mathrm{b}}$ & $82^{\mathrm{b}}$ \\
\hline & $\mathrm{C}$ & $109^{b c}$ & $227^{\mathrm{a}}$ & $15^{\mathrm{a}}$ & $3^{f}$ & $54^{\mathrm{bc}}$ & $143^{\mathrm{a}}$ \\
\hline & NM & 140 & 206 & 10 & 2 & 43 & 95 \\
\hline
\end{tabular}

Means within each column and grouping followed by the same letter are not statistically different at $\mathrm{P}<0.05$.

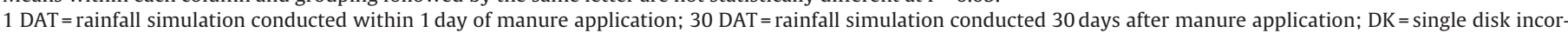
poration, $\mathrm{MP}=$ moldboard plow with single disk incorporation, $\mathrm{NT}=$ no till; $\mathrm{C}=$ composted manure, $\mathrm{S}=$ stockpiled manure, $\mathrm{NM}=$ control or no manure plots.

Table 7

Percentage of hormone loss (\%) in 30 min runoff during the two rainfall events.

\begin{tabular}{|c|c|c|c|c|c|c|c|c|c|}
\hline \multirow[t]{2}{*}{ Tillage } & \multirow[t]{2}{*}{ Manure } & \multicolumn{2}{|c|}{ Estrone } & \multicolumn{2}{|c|}{ 4- anderostenedione } & \multicolumn{2}{|c|}{ Progesterone } & \multicolumn{2}{|c|}{$\beta$-zearalenol } \\
\hline & & $1 \mathrm{DAT}$ & 30 DAT & $1 \mathrm{DAT}$ & 30 DAT & $1 \mathrm{DAT}$ & 30 DAT & $1 \mathrm{DAT}$ & 30 DAT \\
\hline \multirow[t]{2}{*}{ DK } & $\mathrm{S}$ & 0.5 & 0 & 0 & 0 & 0.5 & 0 & 0 & 0.3 \\
\hline & C & 0 & 0.2 & 6.9 & 0.1 & 0 & 0 & 0 & 0 \\
\hline \multirow[t]{2}{*}{ MP } & $\mathrm{S}$ & 0 & 2.8 & 0 & 0.2 & 0.2 & 0.5 & 0 & 0.1 \\
\hline & C & 0 & 0.8 & 0 & 0 & 0 & 1.3 & 0 & - \\
\hline \multirow[t]{2}{*}{ NT } & $\mathrm{S}$ & 1.1 & 0.1 & 0 & 0 & 0.9 & 0 & 0 & 0 \\
\hline & $\mathrm{C}$ & 1.2 & 0 & 0 & 0 & 9.9 & 0 & 0 & 0 \\
\hline
\end{tabular}

runoff is in connection with the phenomenon that soil/sediment bound transport may be the most possible way of its loss in the runoff. For progesterone, there is no sorption study in any type of soil or sediment, to our best knowledge; however, the highest loss $(\sim 10 \%)$ was observed in the NT treatment at 1 DAT rainfall event. It can be recommended that further studies are warranted to understand its transport mechanism in soil-water systems. The low detection of mycotoxin $\beta$-zearalenol can be explained by its microbial transformation as discussed earlier. Mycotoxins are commonly found Fusarium metabolites in row crop fields and detected in several interchangeable forms in nature. Runoff samples confirmed the presence of other three forms of mycotoxin metabolites; although the parent form was almost absent in runoff samples from both rainfall events in all three tillage treatments.

\section{Conclusions}

The current study summarized field research aimed at determining the impact of rainfall timing, tillage, and manure management practices on the occurrence and transport of hormones in surface runoff from manure-amended cropland. The results of study suggested that surface runoff may contain detectable levels of steroid hormones in dissolved form irrespective of tillage and/or manure treatment but that may not be the major contributor of these compounds in the environment. A partial mass balance calculation of four hormones or metabolites demonstrated that there can be maximum $10 \%$ loss through dissolved form in runoff. While extended composting can reduce export of hormones, there was no significant difference in hormones or metabolites concentrations from hormone treated and untreated animal manure. Results of this study suggest that timing of rainfall as well as tillage relative to manure application can be a significant factor in exporting the hormones or metabolites in runoff. In addition to that, several hydrological factors such as rainfall intensity, duration, and timing, runoff, infiltration, initial soil water content as well as soil properties like organic matter content, organic carbon content, and clay content are some of the factors than can impact the transport of hormones in soil-water system.

The low frequency of detections in surface runoff samples suggested that at the recommended manure application rates, sorption to soils and organic matter can limit the transport of hormone losses in runoff. The relatively high partition co-efficient values for many hormones comply with the published literature of their hydrophobic nature in soil-water systems and a significant portion of these hormones may attach with sediment/soil during the first rainfall event. In connection with that, the desorption kinetics as well as the organic carbon content of the soil can be another influential indicator for the transport of those hormones in runoff in between two rainfall events. The possibility of degradation of hormone before the second rainfall event can potentially reduce the losses of hormones in surface runoff, especially from the no-till plots. The $30 \mathrm{~min}$ runoff sample didn't produce enough sediment to determine the sediment-bound concentration of hormones. The results of study will help to comprehend the occurrence and transport of hormones through surface runoff; however, further information will be required (infiltration, soil, and sediment bound transport) to understand the holistic nature of the process.

\section{Acknowledgements}

The study was funded in part by a USEPA Science to Achieve Results (STAR) award no. R833423. We would like to thank Michael Mainz and Leslie Johnson for their technical contribution during the field experiment.

\section{References}

[1] R. Renner, Do cattle growth hormones pose an environmental risk? Environ. Sci. Technol. 36 (9) (2002) 194A-197A.

[2] J. Raloff, Hormones: here's the beef: environmental concerns reemerge over steroids given to livestock, Sci. News 161 (1) (2002) 10-12.

[3] M.G. Bertram, et al., Sex in troubled waters: widespread agricultural contaminant disrupts reproductive behaviour in fish, Horm. Behav. 70 (2015) 85-91. 
[4] B.M. Cleveland, G.M. Weber, Effects of sex steroids on expression of genes regulating growth-related mechanisms in rainbow trout (Oncorhynchus mykiss), Gen. Comp. Endocrinol. 216 (2015) 103-115.

[5] United States Department of Agriculture, A.a.P.H.I.S, Implant usage by U.S. feedlot, in: Info Sheet, Veterinary Services, 2000.

[6] Economic Analysis of the Proposed Revisions to the National Pollutant Discharge Elimination System Regulation and the Effluent Guidelines for Concentrated Animal Feeding Operations, U.S.E.P., Agency, Washington, DC, 2001, Office of Water (4303).

[7] I.G. Lange, et al., Sex hormones originating from different livestock production systems: fate and potential disrupting activity in the environment, Anal. Chim. Acta 473 (1) (2002) 27-37.

[8] Cattle, United States Department of Agriculture, N.A.S.S., 2011.

[9] D. Nichols, et al., Runoff of estrogen hormone $17 \beta$-estradiol from poultry litter applied to pasture, J. Environ. Qual. 26 (4) (1997) 1002-1006.

[10] H.E. Gall, et al., Hormone loads exported by a tile-drained agroecosystem receiving animal wastes, Hydrol. Processes 28 (3) (2014) 1318-1328.

[11] S. Nobel, L. Abrahmsen, U. Oppermann, Metabolic conversion as a pre-receptor control mechanism for lipophilic hormones, Eur. J. Biochem. 268 (15) (2001) 4113-4125.

[12] S. Biswas, et al., Current knowledge on the environmental fate, potential impact, and management of growth-promoting steroids used in the US beef cattle industry, J. Soil Water Conserv. 68 (4) (2013) 325-336.

[13] B. Schiffer, et al., The fate of trenbolone acetate and melengestrol acetate after application as growth promoters in cattle: environmental studies, Environ. Health Perspect. 109 (11) (2001) 1145.

[14] S.L. Bartelt-Hunt, et al., Effect of growth promotants on the occurrence of endogenous and synthetic steroid hormones on feedlot soils and in runoff from beef cattle feeding operations, Environ. Sci. Technol. 46 (3) (2012) 1352-1360.

[15] S.L. Bartelt-Hunt, et al., Effect of composting on the fate of steroids in beef cattle manure, J. Environ. Qual. 42 (4) (2013) 1159-1166.

[16] B.R. Blackwell, et al., Transformation kinetics of trenbolone acetate metabolites and estrogens in urine and feces of implanted steers, Chemosphere 138 (2015) 901-907.

[17] S.L. Shrestha, et al., Fate and transformation of an estrogen conjugate and its metabolites in agricultural soils, Environ. Sci. Technol. 46 (20) (2012) 11047-11053.

[18] S. Qu, E.P. Kolodziej, D.M. Cwiertny, Sorption and mineral-promoted transformation of synthetic hormone growth promoters in soil systems, J. Agric. Food Chem. 62 (51) (2014) 12277-12286.

[19] R. Ma, et al., Influence of soil properties and test conditions on sorption and desorption of testosterone, J. Environ. Eng. 141 (7) (2015) 04015006.

[20] D.S. Mansell, et al., Fate of endogenous steroid hormones in steer feedlots under simulated rainfall-induced runoff, Environ. Sci. Technol. 45 (20) (2011) 8811-8818.

[21] H. Chang, Y. Wan, J. Hu, Determination and source apportionment of five classes of steroid hormones in urban rivers, Environ. Sci. Technol. 43 (20) (2009) 7691-7698.

[22] A.S. Kolok, et al., Occurrence and biological effect of exogenous steroids in the Elkhorn River, Nebraska, USA, Sci. Total Environ. 388 (1-3) (2007) 104-115.

[23] D.W. Kolpin, et al., Phytoestrogens and mycotoxins in iowa streams: an examination of underinvestigated compounds in agricultural basins, J. Environ. Qual. 39 (6) (2010) 2089.

[24] A.M. Soto, et al., Androgenic and estrogenic activity in water bodies receiving cattle feedlot effluent in Eastern Nebraska, USA, Environ. Health Perspect. 112 (3) (2004) 346-352.

[25] E.F. Orlando, et al., Endocrine-disrupting effects of cattle feedlot effluent on an aquatic sentinel species: the fathead minnow, Environ. Health Perspect. 112 (3) (2004) 353-358.

[26] L.S. Shore, A. Pruden, Hormones and pharmaceuticals generated by concentrated animal feeding operations transport in water and soil, in: Emerging Topics in Ecotoxicology 1, Springer Verlag, New York, 2009, p. xii, $147 \mathrm{p}$.

[27] Y. Qi, T.C. Zhang, Sorption of testosterone to soil colloids of different size fractions: development of a centrifugation and mass balance-based methodology, J. Environ. Eng. (2016) 04016059.

[28] Soil Survey of the Dixon County, Nebraska, S.C.S. United States Department of Agriculture and C.a.S.D. University of Nebraska, 1975.

[29] H.P.R.C. Center, Historical Climate Data Summaries: 1964-1998. Northeast Nebraska Exp Stn, Nebraska (256018), 2011 [cited 2011 06/20/2011]; Available from: www.hprcc.unl.edu.

[30] R. Koelsch, C. Shapiro, Determining crop available nutrients from manure, in: Neb Guide, University of Nebraska-Lincoln Extension, 2006.

[31] R.A. Fisher, Statistical Methods for Research Workers, Oliver and Boyd, Edinburgh, UK, 1925.

[32] J. Humphry, et al., A portable rainfall simulator for plot-scale runoff studies, Appl. Eng. Agric. 18 (2) (2002) 199.

[33] W.H. Wischmeier, D.D. Smith, Predicting Rainfall Erosion Losses- a Guide to Conservation Planning, U.S.D.o. Agriculture, Washington, D. C, 1978.
[34] D.D. Snow, et al., Sensitive and simplified analysis of natural and synthetic steroids in water and solids using on-line solid-phase extraction and microwave-assisted solvent extraction coupled to liquid chromatography tandem mass spectrometry atmospheric pressure photoionization, Anal. Bioanal. Chem. 405 (5) (2013) 1759-1771.

[35] T. Montgomery, P. Dew, M. Brown, Optimizing carcass value and the use of anabolic implants in beef cattle, J. Anim. Sci. 79 (E-Suppl) (2001) E296-E306.

[36] R.C. Littell, et al., SAS System for Mixed Models, SAS Institute Inc, Cary, NC, USA, 1996.

[37] H. Hakk, P. Millner, G. Larsen, Decrease in water-soluble 17beta-estradiol and testosterone in composted poultry manure with time, J. Environ. Qual. 34 (3) (2005) 943-950.

[38] N.E. Derby, et al., Effects of composting swine manure on nutrients and estrogens, Soil Sci. 176 (2) (2011) 91-98.

[39] G. Sharp, I. Dyer, Zearalanol metabolism in steers, J. Anim. Sci. 34 (1) (1972) 176-179.

[40] K. Seeling, et al., On the effects of Fusarium toxin-contaminated wheat and the feed intake level on the metabolism and carry over of zearalenone in dairy cows, Food Addit. Contam. 22 (9) (2005) 847-855.

[41] B. Khan, L.S. Lee, Estrogens and synthetic androgens in manure slurry from trenbolone acetate/estradiol implanted cattle and in waste-receiving lagoons used for irrigation, Chemosphere 89 (11) (2012) 1443-1449.

[42] F.X. Casey, et al., Fate and transport of testosterone in agricultural soils, Environ. Sci. Technol. 38 (3) (2004) 790-798.

[43] C. Hildebrand, K.L. Londry, A. Farenhorst, Sorption and desorption of three endocrine disrupters in soils, J. Environ. Sci. Health B 41 (6) (2006) 907-921

[44] Z. Fan, et al., Discerning and modeling the fate and transport of testosterone in undisturbed soil, J. Environ. Qual. 36 (3) (2007) 864-873.

[45] H.E. Gall, et al., Hormone discharges from a midwest tile-drained agroecosystem receiving animal wastes, Environ. Sci. Technol. 45 (20) (2011) 8755-8764.

[46] P. Lafrance, E. Caron, Impact of recent manure applications on natural estrogen concentrations in streams near agricultural fields, Environ. Res. 126 (2013) 208-210.

[47] J.L. Sangster, et al., The effect of particle size on sorption of estrogens, androgens and progestagens in aquatic sediment, J. Hazard. Mater. 299 (2015) $112-121$.

[48] W.F. Young, et al., Proposed Predicted-No-Effect-Concentrations (PNECs) for Natural and Synthetic Steroid Oestrogens in Surface Waters, Environment Agency, Buckinghamshire, UK, 2004.

[49] K. Barel-Cohen, et al., Monitoring of natural and synthetic hormones in a polluted river, J. Environ. Manage. 78 (1) (2006) 16-23.

[50] Y.Y. Yang, et al., Steroid hormone runoff from agricultural test plots applied with municipal biosolids, Environ. Sci. Technol. 46 (5) (2012) 2746-2754.

[51] P.B. Delaune, P.A. Moore Jr., 17beta-estradiol in runoff as affected by various poultry litter application strategies, Sci. Total Environ. 444 (2013) 26-31.

[52] F.S. Zhang, et al., Accumulation of steroid hormones in soil and its adjacent aquatic environment from a typical intensive vegetable cultivation of North China, Sci. Total Environ. 538 (2015) 423-430.

[53] T.D. Bucheli, et al., Fusarium mycotoxins: overlooked aquatic micropollutants? J. Agric. Food Chem. 56 (3) (2008) 1029-1034.

[54] G. Wilson, et al., Tillage and residue effects on runoff and erosion dynamics, Trans. ASAE 47 (1) (2004) 119.

[55] M.B. Jenkins, et al., 17beta-Estradiol and testosterone in drainage and runoff from poultry litter applications to tilled and no-till crop land under irrigation, J. Environ. Manage. 90 (8) (2009) 2659-2664.

[56] S. Dutta, et al., Free and conjugated estrogen exports in surface-runoff from poultry litter-amended soil, J. Environ. Qual. 39 (5) (2010) 1688.

[57] S. Biswas, et al., Use of a surrogate to evaluate the impact of tillage on the transport of steroid hormones from manure-amended agricultural fields, Trans. ASABE 56 (4) (2013) 1379-1385.

[58] M.L. Mashtare, B. Khan, L.S. Lee, Evaluating stereoselective sorption by soils of 17alpha-estradiol and 17beta-estradiol, Chemosphere 82 (6) (2011) 847-852.

[59] A.K. Sarmah, G.L. Northcott, F.F. Scherr, Retention of estrogenic steroid hormones by selected New Zealand soils, Environ. Int. 34 (6) (2008) 749-755.

[60] L.S. Lee, et al., Sorption and dissipation of testosterone, estrogens, and their primary transformation products in soils and sediment, Environ. Sci. Technol. 37 (18) (2003) 4098-4105.

[61] M.L. Card, et al., Prediction and experimental evaluation of soil sorption by natural hormones and hormone mimics, J. Agric. Food Chem. 60 (6) (2012) 1480-1487.

[62] B. Das, et al., Sorption and degradation of steroid hormones in soils during transport: column studies and model evaluation, Environ. Sci. Technol. 38 (5) (2004) 1460-1470.

[63] G.G. Ying, R.S. Kookana, Sorption and degradation of estrogen-like-endocrine disrupting chemicals in soil, Environ. Toxicol. Chem. 24 (10) (2005) 2640-2645.

[64] B. Khan, X. Qiao, L.S. Lee, Stereoselective sorption by agricultural soils and liquid- liquid partitioning of trenbolone $(17 \alpha$ and $17 \beta)$ and trendione, Environ. Sci. Technol. 43 (23) (2009) 8827-8833. 